\title{
МЕТАБОЛИЧЕСКАЯ АКТИВНОСТЬ КУЛЬТУРАЛЬНОЙ ЖИДКОСТИ КСЕНОГЕННЫХ, АЛЛОГЕННЫХ ГЕПАТОЦИТОВ И ФИБРОБЛАСТОВ В УСЛОВИЯХ ЭКСПЕРИМЕНТАЛЬНОГО ОСТРОГО ТЕТРАХЛОРМЕТАНОВОГО ПОРАЖЕНИЯ ПЕЧЕНИ
}

\author{
(C) Разумова М.С. , Литвинова Е.C. ${ }^{1}$, Быстрова Н.A. ${ }^{2}$, Чуева T.В. ${ }^{3}$ \\ ${ }^{1}$ Кафедра патологической анатомии, ${ }^{2}$ кафедра биологической химии, ${ }^{3}$ кафедра анатомии человека \\ Курского государственного медицинского университета, Курск
}

E-mail: kat roma@mail.ru

\begin{abstract}
При экспериментальном остром токсическом тетрахлометановом поражении печени установлено развитие основных биохимических синдромов поражения печени (цитолиза, внутрипеченочного и внепеченочного холестаза, внутриклеточного холестаза с желтухой и токсическим поражением гепатоцитов, недостаточности синтетических процессов, воспалительного) и активация свободнорадикального окисления на системном и локальном (эритроциты) уровне. Гуморальные факторы культуральной жидкости фетальных гепатоцитов аллогенных реципиентов с острой токсической гепатопатией наиболее эффективно, по сравнению с культуральной жидкостью ксеногенных гепатоцитов и фибробластов, корригируют системные и локальные метаболические нарушения, возникающие вследствие воздействия гепатотропного яда.
\end{abstract}

Ключевые слова: метаболические нарушения, острое токсическое поражение печени, культуральная жидкость ксено- и аллогенных гепатоцитов, фибробластов.

\section{METABOLIC ACTIVITIES OF CULTURE FLUID OF XENOGENIC, ALLOGENEIC HEPATOCYTES AND FIBROBLASTS IN EXPERIMENTAL ACUTE LIVER DAMAGE BY TETRACHLORMETAN Razumova M.S. ${ }^{1}$, Litvinova E.S. ${ }^{1}$, Bystrova N.A. ${ }^{2}$, Chueva T.V. ${ }^{3}$}

${ }^{1}$ Department of Pathological Anatomy, ${ }^{2}$ Department of Biological Chemistry, ${ }^{3}$ Department of Human Anatomy of Kursk State Medical University, Kursk

The development of basic biochemical syndromes of liver damage (cytolysis, intrahepatic and extrahepatic cholestasis, intracellular cholestasis with jaundice and toxic lesions of hepatocytes, insufficient synthetic processes, insufficiency inflammation) and activation of free radical oxidation at systemic and local (erythrocytes) levels was established in experimental acute toxic tetrachlormetan liver damage. Humoral factors of culture fluid of fetal hepatocytes in allogeneic recipients with acute toxic hepatopathy correct the systemic and local metabolic disorders arising due to hepatotropic poison exposure more effectively as compared to culture fluid of xenogeneic hepatocytes and fibroblasts.

Keywords: metabolic disorders, acute liver toxicity, the culture fluid xeno-, allogenic hepatocytes, fibroblasts.

Большой экспериментальный и клинический материал, накопленный за последние годы, показывает, что клеточную терапию можно рассматривать как одно из приоритетных направлений в современной биомедицине и биотехнологии $[14,15,17,25]$.

Эффективность замещения клеточных дефектов печени при врожденных и приобретенных заболеваниях, способность стимулировать собственную регенерацию органа, отсутствие опасностей возникновения фиброзов зависят главным образом от используемых клеток. В ряде исследований показано, что при определенных условиях культивирования клетки различного типа способны экспрессировать специфичные для гепатоцитов маркеры. Однако истинная функциональность тех или иных клеток остается недоказанной, поэтому актуальными являются исследования по изучению метаболической активности ксено- и аллогенных трансплантатов $[6,12,16,28]$.
В условиях острой токсической гепатопатии, классической моделью которой является отравление четыреххлористым углеродом (ЧХУ), так же как и при других поражениях печени, изменяется иммунологическая реактивность, при этом требуется коррекция функциональной активности не только гепатоцитов, но и иммунокомпетентных клеток $[5,7,19]$.

Известно, что супернатант эмбриональных фибробластов подавляет способность нейтрофилов к адгезии in vitro, повышает спонтанную активность кислород-зависимых и кислороднезависимых микробицидных факторов в нейтрофилах здоровых доноров и способствует снижению интенсивности механизмов респираторного взрыва в нейтрофилах в условиях воздействия провоспалительных факторов, способен оказывать разнонаправленное влияние на продукцию TNF- $\alpha$ и IL-1 $\beta$, способствуя ее умеренной активации в спонтанных условиях и подавляя в условиях действия провоспалительных факторов. Кроме этого, фибробласты способ- 
ны не только к активации иммунокомпетентных клеток. Среди продуцируемых фибробластами растворимых медиаторов значительное место занимают ростовые факторы - FGF, EGF, TGF и др. При этом отмечено, что некоторые из ростовых факторов, в частности IGF-1, EGF, PDGF, TGF-в, могут непосредственно супрессировать пролиферацию иммунокомпетентных клеток и/или препятствовать реализации их цитотоксического потенциала [3, 4, 27$]$.

Исходя из этого, целью исследования стало изучение влияния гуморальных факторов культуральной жидкости ксено-, аллогенных гепатоцитов и фибробластов на системные и локальные метаболические нарушения в условиях экспериментального острого токсического поражения печени.

\section{МАТЕРИАЛЫ И МЕТОДЫ ИССЛЕДОВАНИЯ}

Исследования проведены на 88 крысах породы Вистар массой 90-180 г. В опытах использовали животных, прошедших карантинный режим вивария Курского государственного медицинского университета и не имевших внешних признаков каких-либо заболеваний. Все животные содержались в одинаковых условиях, на обычном пищевом режиме. Для получения статистически достоверных результатов группы формировали из 10-12 животных. В контрольные и опытные группы входили животные одного возраста, полученные из питомника одновременно. Разброс в группах по исходной массе не превышал $\pm 10 \%$. Все исследования проводили в одно и то же время суток, с 8 до 12 часов, с соблюдением принципов, изложенных в Конвенции по защите позвоночных животных, используемых для экспериментальных и других целей (г. Страсбург, Франция, 1986), и согласно правилам лабораторной практики РФ (приказ МЗ РФ № 267 от 19.06.2003). Животных выводили из опыта на шестые сутки декапитацией под эфирным наркозом после первого введения четыреххлористого углерода (ЧХУ) и культуральной жидкости ксено-, аллогенных гепатоцитов или фибробластов.

ОТПП (острое токсическое поражение печени) у лабораторных животных моделировали путем внутримышечного введения четыреххлористого углерода (ЧХУ) в дозе 3 мл/кг в виде $50 \%$ раствора в оливковом масле пятикратно с интервалом 24 [1, 7, 19].

Выделение ксеногенных (мышиных) и аллогенных гепатоцитов от новорожденных животных производилась по методике M.N. Berry,
D.S. Friend [26]. Фибробласты выделяли из фрагментов туловища и конечностей тканей 8-12-недельного абортуса человека путем их механической дезинтеграции до микрофрагментов размером 0,1-0,2 мм и дальнейшего выращивания клеток [25]. Жизнеспособность клеток определяли в тесте исключения красителя - трипанового синего, при этом клеточные суспензии, содержащие менее 90\% жизнеспособных клеток, не использовали.

С целью получения культуральной жидкости мышиных и аллогенных гепатоцитов (КЖМГ, КЖАГ) в среде 199 культивировали $5 \times 10^{7}$ клеток на 3 мл среды, содержащей 5\% телячьей эмбриональной сыворотки, в течение 6 ч. После истечения срока инкубации клетки осаждали центрифугированием (15 мин при 400 g) [13, 22]. Концентрацию белка в культуральной жидкости определяли с использованием красителя Кумаси G-250 по Брефорд.

Полученные КЖМГ и КЖАГ вводили с первой инъекцией гепатотропного яда пятикратного (с 24-часовым интервалом) внутрибрюшинно крысам с ОТПП из расчета 5 мг/кг белка.

В качестве источника продуцируемых фибробластами гуморальных факторов использовали кондиционированную человеческими фетальными фибробластами полную культуральную среду (альфа-MEM (AppliChem, Германия) с 10\% сыворотки эмбрионов коров (HyClone, США), которую забирали после трехсуточного культивирования в ней клеток, начиная с концентрации 15 х $10^{4}$ мл и до формирования ими монослоя на дне флакона (на вторые сутки). Указанный клеточный супернатант (КСФБ) вводили внутрибрюшинно в объеме 35 мг/кг с ОТПП.

Для оценки функционального состояния гепатоцитов в плазме крови определяли активность аспартат- и аланинаминотрансфераз (АСТ, АЛТ), щелочной фосфатазы (ЩФ), гаммаглутаминтранспептидазы (ГГТ), содержание билирубина (БР) и протромбиновый индекс (ПТИ). Концентрацию фибриногена (ФГ) исследовали методом Рутберг. Величины всех перечисленных показателей определяли унифицированными методами с использованием стандартных наборов реактивов.

Интенсивность процессов перекисного окисления липидов (ПОЛ) оценивали по содержанию в плазме крови ацилгидроперекисей (АГП) и малонового диальдегида (МДА) [20]. Кроме этого, определяли активность каталазы (Кат) и супероксиддисмутазы (СОД) [10]. Общую антиокислительную активность (ОАА) плазмы крови определяли методом, основанным на 
степени ингибирования аскорбат- и ферроиндуцированного окисления твина- 80 до МДА. Концентрацию стабильных метаболитов оксида азота $\left(\mathrm{CM}_{\mathrm{NO}}\right)$ исследовали спектрофотометрически с помощью реактива Грисса.

Подсчет общего количества эритроцитов и содержания гемоглобина проводили по общепринятым методикам. Кроме этого, определяли сорбционную способность эритроцитов (ССЭ) [21] и сорбционную емкость их гликокаликса (СЕГ) [18]. О метаболическом состоянии эритроцитов судили по внутриклеточной концентрации МДА, АГП и активности СОД.

Статистическую обработку результатов исследования проводили по общепринятым критериям вариационно-статистического анализа с вычислением средних величин (М), ошибки средней арифметической (m) с помощью пакета компьютерных программ Microsoft Excel, 2010. Существенность различий оценивали по U-критерию. Статистически значимыми считали различия $\mathrm{c} \mathrm{p}=0,05$ [11]. Степень расстройств лабораторных показателей рассчитывали по формуле [8]:

$$
\left(\frac{\text { показатель опытных животных }}{\text { показатель здоровых животных }}-1\right) \times 100 \%
$$

Примечание: в интервале от 1 до $33 \%$ полученная величина соответствует первой степени лабораторных расстройств, от 34 до $66 \%$ - второй, более $66 \%$ - третьей.

\section{РЕЗУЛЬТАТЫ ИССЛЕДОВАНИЯ И ИХ ОБСУЖДЕНИЕ}

У животных с пятикратным отравлением ЧХУ выявлено развитие основных биохимических синдромов поражения печени: цитолиза (увеличение активности АСТ на 47\%, АЛТ на 75\% снижение коэффициента де Ритиса на 52,3\%), внутрипеченочного и внепеченочного холестаза (повышение активности ЩФ на 49,9\% и ГГТ на $69,9 \%$ ), внутриклеточного холестаза с желтухой и токсическим поражением гепатоцитов (увеличение содержания Б на 70,8\%, активности АЛТ, АСТ, ЩФ, ГГТ, значения коэффициентов де Ритиса и ГГТ/АСТ меньше 1), недостаточности синтетических процессов (снижение ПТИ на $24,9 \%$ и ФБ на $43,9 \%$ ) и воспалительного (повышение ТП на 41,9\%) (табл. 1).

Одновременное с отравлением ЧХУ введение КЖМГ, по сравнению с только ОТПП, нормализует активность ЩФ, ГГТ и корригирует в сторону здоровых животных остальные показатели, характеризующие функциональнометаболическую активность гепатоцитов. Введение КЖФБ корригирует активность АЛТ, ЩФ, ГГТ, коэффициеты соотношения АСТ/АЛТ, ГГТ/АСТ, концентрацию БР и ФГ. Наиболее эффективным оказалось применение КЖАГ, т.к. ее введение нормализовало и корригировало в сторону нормы по $50 \%$ исследованных показателей функционально-метаболической активности гепатоцитов (табл. 1).

Влияние культуральной жидкости ксено-, аллогенных гепатоцитов и фибробластов на функциональную активность гепатоцитов при экспериментальном остром токсическом поражении печени $(\mathrm{M} \pm \mathrm{m})$

\begin{tabular}{|c|c|c|c|c|c|c|}
\hline \multirow[b]{3}{*}{ Показатели } & \multirow{3}{*}{$\begin{array}{c}\text { Единицы } \\
\text { измерения }\end{array}$} & 1 & 2 & 3 & 4 & 5 \\
\hline & & \multirow[b]{2}{*}{ Контроль } & \multicolumn{4}{|c|}{ Отравление ЧХУ и введение культуральной жидкости: } \\
\hline & & & - & $\begin{array}{c}\text { ксеногенных } \\
\text { гепатоцитов } \\
\text { мыши }\end{array}$ & фибробластов & $\begin{array}{l}\text { аллогенных } \\
\text { гепатоцитов }\end{array}$ \\
\hline $\mathrm{ACT}$ & $\mathrm{E} /$ Л & $29,2 \pm 2,4$ & $55,1 \pm 4,2^{* 1}$ & $40,1 \pm 2,2^{* 1,2}$ & $51,2 \pm 4,1^{* 1,3}$ & $30,3 \pm 2,7^{* 2-4}$ \\
\hline АЛТ & $\mathrm{E} /$ /л & $22,4 \pm 1,9$ & $89,5 \pm 5,1^{* 1}$ & $53,0 \pm 3,7^{* 1,2}$ & $60,8 \pm 4,5^{* 1,2}$ & $34,8 \pm 3,3^{* 1-4}$ \\
\hline ЩФ & $\mathrm{E} /$ Л & $231,5 \pm 17,9$ & $461,8 \pm 34,2^{* 1}$ & $262,3 \pm 15,8^{* 2}$ & $306,7 \pm 14,2^{* 1-3}$ & $263,3 \pm 12,1^{* 2,4}$ \\
\hline \multicolumn{2}{|c|}{$\begin{array}{c}\text { Коэффициент } \\
\text { де Ритиса, АСТ/АЛТ }\end{array}$} & $1,3 \pm 0,03$ & $0,62 \pm 0,05^{* 1}$ & $0,76 \pm 0,04^{* 1,2}$ & $0,84 \pm 0,04^{* 1,2}$ & $0,87 \pm 0,05^{* 1-4}$ \\
\hline ГГТ & Е/л & $5,9 \pm 0,2$ & $19,6 \pm 2,2^{* 1}$ & $5,6 \pm 0,4^{* 2}$ & $8,9 \pm 0,8^{* 1-3}$ & $5,6 \pm 0,4^{* 2,4}$ \\
\hline \multicolumn{2}{|c|}{ ГГТ/АCТ } & $0,2 \pm 0,01$ & $0,36 \pm 0,02^{* 1}$ & $0,14 \pm 0,02^{* 1,2}$ & $0,17 \pm 0,01^{* 1,2}$ & $0,18 \pm 0,02^{* 2}$ \\
\hline БР & мкмоль/л & $5,4 \pm 0,3$ & $18,5 \pm 1,2^{* 1}$ & $6,7 \pm 0,4^{* 1,2}$ & $10,9 \pm 1,1^{* 1-3}$ & $6,3 \pm 0,3^{* 1,2,4}$ \\
\hline ПТИ & $\%$ & $62,3 \pm 3,8$ & $46,8 \pm 3,5^{* 1}$ & $53,2 \pm 3,1^{* 1,2}$ & $47,8 \pm 3,2^{* 1}$ & $56,1 \pm 3,1^{* 2,4}$ \\
\hline$\Phi \Gamma$ & г/л & $4,1 \pm 0,1$ & $2,3 \pm 0,03^{* 1}$ & $3,3 \pm 0,04^{* 1,2}$ & $3,4 \pm 0,02^{* 1,2}$ & $3,8 \pm 0,1^{* 1-4}$ \\
\hline ТП & Ед. S-H & $2,5 \pm 0.04$ & $4,3 \pm 0,1^{* 1}$ & $3,1 \pm 0,06^{* 1,2}$ & $4,0 \pm 0,2^{* 1,3}$ & $3,0 \pm 0,05^{* 1,2,4}$ \\
\hline
\end{tabular}

Примечание: на этой и в таблицах 2 и 3 звездочкой $(*)$ отмечены достоверные отличия средних арифметических (р<0,05); Цифры рядом со звездочкой - по отношению к показателям какой группы даны эти различия. 
Таблица 2

Влияние культуральной жидкости ксено-, аллогенных гепатоцитов и фибробластов на состояние перекисного окисления липидов, факторы антиоксидантной защиты, уровень стабильных метаболитов оксида азота при остром токсическом поражении печени $(\mathrm{M} \pm \mathrm{m})$

\begin{tabular}{|c|c|c|c|c|c|c|}
\hline & & 1 & 2 & 3 & 4 & \multicolumn{2}{c|}{5} \\
\cline { 4 - 7 } Показатели & \multirow{2}{*}{$\begin{array}{c}\text { Единицы } \\
\text { измерения }\end{array}$} & \multirow{2}{*}{ Контроль } & \multicolumn{2}{|c|}{ Отравление ЧХУ и введение культуральной жидкости: } \\
\cline { 4 - 7 } & & - & $\begin{array}{c}\text { ксеногенных } \\
\text { гепатоцитов } \\
\text { мыши }\end{array}$ & фибробластов & $\begin{array}{c}\text { аллогенных } \\
\text { гепатоцитов }\end{array}$ \\
\hline МДА & мкмоль/л & $2,2 \pm 0,04$ & $5,8 \pm 0,2^{* 1}$ & $3,2 \pm 0,1^{* 1,2}$ & $3,4 \pm 0,1^{* 1,2}$ & $2,3 \pm 0,07^{* 2-4}$ \\
\hline АГП & усл. ед. & $0,75 \pm 0,04$ & $2,1 \pm 0,4^{* 1}$ & $0,88 \pm 0,05^{* 1,2}$ & $0,89 \pm 0,03^{* 1,2}$ & $0,74 \pm 0,04^{* 2-4}$ \\
\hline ОАА & $\%$ & $40,3 \pm 1,1$ & $33,0 \pm 2,0^{* 1}$ & $42,6 \pm 2,5^{* 2}$ & $41,0 \pm 4,0^{* 2}$ & $43,8 \pm 3,6^{* 2}$ \\
\hline СОД & усл. ед./мл & $11,3 \pm 0,6$ & $8,4 \pm 0,5^{* 1}$ & $9,9 \pm 0,4^{* 1,2}$ & $9,2 \pm 0,5^{* 1,2}$ & $12,0 \pm 0,7^{* 2-4}$ \\
\hline Кат & мкат/л & $12,4 \pm 0,5$ & $9,2 \pm 0,6^{* 1}$ & $12,6 \pm 0,9^{* 2}$ & $11,9 \pm 1,3^{* 2}$ & $15,4 \pm 1,2^{* 1-4}$ \\
\hline СМ $_{\text {NO }}$ & мкмоль/л & $6,9 \pm 0,2$ & $2,9 \pm 0,05^{* 1}$ & $2,7 \pm 0,2^{* 1}$ & $3,3 \pm 0,1^{* 1-3}$ & $4,9 \pm 0,2^{* 1-4}$ \\
\hline
\end{tabular}

Таблица 3

Влияние культуральной жидкости ксено-, аллогенных гепатоцитов и фибробластов на метаболическую активность эритроцитов периферической крови при остром токсическом поражении печени $(\mathrm{M} \pm \mathrm{m})$

\begin{tabular}{|c|c|c|c|c|c|c|}
\hline \multirow{2}{*}{ Показатели } & \multirow{2}{*}{$\begin{array}{c}\text { Единицы } \\
\text { измерения }\end{array}$} & \multirow{2}{*}{ Контроль } & \multicolumn{2}{|c|}{ Отравление ЧХУ и введение культуральной жидкости: } \\
\cline { 4 - 7 } & & - & $\begin{array}{c}\text { ксеногенных } \\
\text { гепатоцитов } \\
\text { мыши }\end{array}$ & фибробластов & $\begin{array}{c}\text { аллогенных } \\
\text { гепатоцитов }\end{array}$ \\
\hline $\begin{array}{c}\text { Количество } \\
\text { эритроцитов }\end{array}$ & $10^{12} /$ л & $4,1 \pm 0,07$ & $3,3 \pm 0,03^{* 1}$ & $4,1 \pm 0,1^{* 2}$ & $4,1 \pm 0,3^{* 2}$ & $4,3 \pm 0,3^{* 2}$ \\
\hline Нь & г/л & $14,7 \pm 0,4$ & $13,7 \pm 0,3^{* 1}$ & $14,6 \pm 0,5^{* 2}$ & $14,4 \pm 0,7^{* 2}$ & $14,5 \pm 0,9^{* 2}$ \\
\hline МДА & мкмоль/л & $0,3 \pm 0,02$ & $0,63 \pm 0,02^{* 1}$ & $0,29 \pm 0,04^{* 2}$ & $0.34 \pm 0,02^{* 2}$ & $0,32 \pm 0,02^{* 2}$ \\
\hline АГП & усл. ед. & $0,12 \pm 0,02$ & $0,5 \pm 0,02^{* 1}$ & $0,2 \pm 0,01^{* 1,2}$ & $0,22 \pm 0,02^{* 1,2}$ & $0,11 \pm 0,01^{* 2-4}$ \\
\hline СОД & усл. ед./мл & $24,2 \pm 1,5$ & $9,1 \pm 0,3^{* 1}$ & $14,4 \pm 0,8^{* 1,2}$ & $16,8 \pm 1,1^{* 1-3}$ & $20,1 \pm 1,2^{* 1-4}$ \\
\hline СЕЭ & $\%$ & $50,6 \pm 1,6$ & $28,8 \pm 3,8^{* 1}$ & $46,3 \pm 3,8^{* 2}$ & $48,5 \pm 2,7^{* 2}$ & $51,0 \pm 2,5^{* 2}$ \\
\hline СЕГ & $10^{12}$ г/эр & $2,9 \pm 0,09$ & $1,8 \pm 0,05^{* 1}$ & $2,6 \pm 0,1^{* 1,2}$ & $2,5 \pm 0,2^{* 1,2}$ & $2,8 \pm 0,2^{* 2}$ \\
\hline
\end{tabular}

При изучении уровня стабильных метаболитов оксида азота, состояния ПОЛ и факторов антиоксидантной защиты при ОТПП было установлено, что у отравленных животных повышены процессы ПОЛ (повышен уровнь МДА на $62,1 \%$ и АГП на $64,3 \%$ ), снижены показатели антиоксидантной защиты (OAA на 18,1\%, активность СОД на $22,1 \%$ и Кат на $25,8 \%$ ) и концентрация $\mathrm{CM}_{\mathrm{NO}}$ на $58 \%$ (табл. 2).

Введение КЖМГ нормализует ОАА и активность Кат и корригирует, но не до показателей контрольной группы, содержание продуктов ПОЛ и активность СОД. Применение КЖФБ приводит к такому же эффекту, но дополнительно корригирует уровень стабильных метаболитов оксида азота. Введение КЖАГ нормализует ОАА, концентрацию МДА, АГП, активность СОД, повышает выше значений нормы активность каталазы и корригирует содержание $\mathrm{CM}_{\mathrm{NO}}$ (табл. 2).
При оценке показателей метаболизма эритроцитов установлено, что при пятидневном введении гепатотоксического яда наблюдается снижение их общего количества, гемоглобина, сорбционных показателей, повышение МДА, АГП и активности СОД (табл. 3).

Применение КЖМГ или КЖФБ нормализует общее количество эритроцитов, содержание в них гемоглобина, сорбционную способность эритроцитов (СЕЭ) и корригирует в сторону значений нормальных показателей концентрацию АГП, активность СОД и сорбционную емкость гликокаликса эритроцитов (СЕГ). Введение экспериментальным животным с ОТПП КЖАГ корригирует СЭГ, активность СОД и нормализует остальные показатели метаболизма эритроцитов (табл. 3). 
Таблица 4

Сравнительное влияние влияние культуральной жидкости ксено-, аллогенных гепатоцитов и фибробластов на метаболические показатели плазмы крови и эритроцитов в условиях острого токсического поражения печени

\begin{tabular}{|c|c|c|c|c|c|c|c|c|}
\hline \multirow{3}{*}{ Условия опыта } & \multirow{2}{*}{\multicolumn{2}{|c|}{$\begin{array}{c}\text { Измененные } \\
\text { лабораторные } \\
\text { показатели }\end{array}$}} & \multicolumn{6}{|c|}{$\begin{array}{c}\text { Измененные лабораторные показатели } \\
\text { по степени расстройств }\end{array}$} \\
\hline & & & \multicolumn{2}{|c|}{ I } & \multicolumn{2}{|c|}{ II } & \multicolumn{2}{|c|}{ III } \\
\hline & абс. & $\%$ & абс. & $\%$ & абс. & $\%$ & абс. & $\%$ \\
\hline Отравление ЧХУ & 23 & 100 & 3 & 13,1 & 9 & 39,1 & 11 & 47,8 \\
\hline Отравление ЧХУ и введение КЖКГ & 15 & 65,2 & 8 & 34,8 & 6 & 26,1 & 1 & 4,3 \\
\hline Отравление ЧХУ и введение КЖФБ & 17 & 73,9 & 7 & 30,4 & 6 & 26,1 & 4 & 17,4 \\
\hline Отравление ЧХУ и введение КЖАГ & 7 & 30,4 & 6 & 26,1 & 1 & 4,3 & - & - \\
\hline
\end{tabular}

При количественном сопоставлении числа нарушенных показателей в различных условиях опыта с делением глубины нарушений по степеням установлено, что при введении ЧХУ в течение пяти дней нарушенными из 23 исследованного лабораторного показателя оказались $100 \%$, из которых соответственно 3, 2 и 1 степени $47,8 \%$ - 39,1\% и $13,1 \%$. Введение НЖМГ в течение периода интоксикации снижает число нарушенных лабораторных показателей до 17 $(65,2 \%)$, со значительным уменьшением глубины нарушений 2 и 3 степени, что требует обязательной фармакологической коррекции [14]. Соответственно по мере снижения степени нарушений установлены следующие \%: 4,3 - 26,1 - 34,8. Применение НЖФБ снизило количество измененных показателей до $17(73,9 \%)$, а по степеням $3-2-1$ соответственно $17,4 \%-26,1 \%$ и $30,4 \%$. В большей мере оказалось эффективным введение НЖАГ, т.к. измененными остались только семь показателей, из них оказалось только второй степени 4,3\% и первой $26,1 \%$ (табл. 4).

Полученные нами данные позволяют заключить, у животных на фоне пятидневной интоксикации ЧХУ наблюдается развитие основных биохимических синдромов поражения печени: цитолиза, внутрипеченочного и внепеченочного холестаза, внутриклеточного холестаза с желтухой и токсическим поражением гепатоцитов, недостаточности синтетических процессов и воспалительного. Кроме этого, выявлена активация свободнорадикального окисления, являющегося фактором патогенеза многих заболеваний $[9,23]$.

Первичные гепатоциты стали первым типом клеток, использованных для клинических целей клеточной терапии больных с врожденными и приобретенными дефектами печени. По сравнению с клетками-предшественниками и стволовыми клетками, культуры первичных гепатоцитов обладают очень ограниченной способностью к делению, что является серьезным лимитирующим фактором для их практического использования. Эффективность трансплантации гепатоцитов существенно ограничивается в результате развития нарушений иммунного гомеостаза $[12,14,24]$.

Гуморальные факторы культуральной жидкости гепатоцитов интактных крыс аллогенным реципиентам в условиях острого токсического поражения печени наиболее эффективно, по сравнению с культуральной жидкостью ксеногенных гепатоцитов и фибробластов, корригирует системные и локальные метоболическаие нарушения, возникающие вследствие воздействия гепатотропного яда.

Для более широкого внедрения заместительной клеточной терапии в клиническую практику необходимы дальнейшие экспериментальные исследования, направленные на определение иммунометаболических эффектов различных вариантов регенеративной клеточной терапии (использование ксено- и аллогенных трансплантатов и их культуральной жидкости), а также их сочетанное применение с фармакологическими препаратами при патологии печени.

\section{ЛИТЕРАТУРА}

1. Алексеева И.Н. Противопеченочные антитела и функции печени. - Киев : Наукова думка, 1980. $183 \mathrm{c}$.

2. Бенеманский В.В., Никифоров С.Б., Ильина В.В. Влияние неонатальных гепатоцитов на липидный обмен, морфологические изменения аорты и печени в условиях гиперхолестеринемии алиментарного и токсического характера / Бюллетень ВСНЦ СО РАМН. - 2005. - № 2 (40). C. $167-175$.

3. Бурда Ю.Е., Конопля А.И., Ершов Д.В. Влияние комплекса гуморальных факторов, продуци-руемых фибробластами, на адгезивную способность клеток-участниц воспаления in vitro / Современные наукоемкие технологии. - 2005. - № 4. C. $86-88$.

4. Бурда Ю.Е. Влияние супернатанта аллогенных фибробластов на функциональную активность нейтрофилов и продукцию интерлейкина-8 in 
vitro // Мед. иммунология . - 2003. - Т. 5, № 3-4. C. 247-248.

5. Дудка В.Т., Пигарева А.В., Конопля А.И., Романова Е.С., Гаврилюк В.П. Функциональная активность гепатоцитов в условиях острого токсического поражения печени и воздействия постоянного магнитного поля // Системный анализ и управление в биомедицинских системах. 2006. - T. 5, № 2. - С. 223-225.

6. Жексенова А.Н., Насыров И.Н., Калдыбаева А.Т., Батырова Т.Ж., Альмаханова М.Ж. Морфологическое изменение в лимфоузлах при воспалительном процессе у крыс на фоне воздействия фетальными гепатоцитами // Аллергология и иммунология. - 2015. - Т. 16, № 3. - С. 311 .

7. Забродский П.Ф., Громов М.С., Масляков В.В. Коррекция токоферола ацетатом и унитолом нарушений иммунного гомеостаза крыс при острой интоксикации тетрахлорметаном // Экспериментальная и клиническая фармакология. -2015 . - Т. 78, № 1. - С. 30-33.

8. Земсков А.М., Земсков В.М., Новикова Л.А. Избранные проблемы иммунологии. - Воронеж : Изд-во Воронежского государственного университета, 1997. - 208 с.

9. Конопля А.А., Караулов А.В., Конопля А.И., Гаврилюк В.П. Взаимосвязь коррекции иммунных и оксидантных нарушений со структурнофункциональными свойствами эритроцитов при хронических сальпингоофоритах. - Курск : Изд-во ГОУ ВПО КГМУ Росздрава, 2009. - 180 с.

10. Костюк В.А., Потапов А.Н., Ковалева Ж.В. Простой и чувствительный метод определения супероксиддисмутазы, основанный на реакции окисления кверцетина // Вопросы медицинской химии. - 1990. - № 2. - С. 88-91.

11. Лакин Г.Ф. Биометрия. - М. : Высшая школа, 1980. -243 c.

12. Лепехова С.А., Апаричин К.А., Зариџкая Л.В., Постовая О.Н., Батунова Е.В., Прокопьев М.В., Каргин А.Г., Рой Т.А., Коваль Е.В. Влияние ксенотрансплантации культуры клеток печени на изменения неспецифической резистентности организма при остром токсическом повреждении печени // Сибирский медицинский журнал. 2009. - № 7. - C. 101-104.

13. Литвинова Е.С., Терехова С.В., Быстрова Н.А., Гаврилюк В.П. Иммунометаболический статус у интактных животных при введении культуральной жидкости аллогенных гепатоцитов, гептрала и мексикора // Врач-аспирант. - 2012. - № 3.2 (52). C. 315-319.

14. Люндуn А.В., Онищенко Н.А., Шагидулин М.Ю., Крашенников M.E. Стволовые прогениторные клетки печени и костного мозга как регуляторы восстановительной регенерации поврежденной печени // Вестник трансплантологии и искусственных органов. - 2010. - Т. ХІІ, № 2. C. 100-107.

15. Медведева С.Ю., Мухлынина Е.А., Булавинцева Т.С., Данилова И.Г. Участие фактора стволовой клетки в репаративной регенерации печени при ее токсическом повреждении // Медицинская иммунология. - 2015. - Т. 17, спец. выпуск. - С. 32.

16. Онищенко H.A. Клеточные технологии и современная медицина // Патологическая физиология и экспериментальная терапия. 2004. - № 4. - С. 2-11.

17. Онищенко Н.А., Люндуп А.В., Газизов И.М., Деев Р.В., Шагидулин М.Ю., Крашенинников М.Е., Аврамов П.В. Двухфазная динамика воздействия мезенхимальных мультпатентных стромальных клеток (ММСК) костного мозга на печень при моделировании фиброзирующего гепатита // Вестник трансплантологии и искусственных органов. - 2011. - Т. XIII, № 3. - С. 51-58.

18. Семко Г.А. Структурно-функциональные изменения мембран и внешних примембранных слоев эритроцитов при гиперэпидермопоэзе // Украинский биохимический журнал. - 1998. Т. 70, № 3. - С. 113-118.

19. Смахтин М.Ю., Конопля А.И., Северьянова Л.А., Швейнов И.А. Фармакологическая коррекция пептидом GLY-HIS-LYS иммунологических нарушений в условиях поражения печени тетрахлорметаном / Патологическая физиология и экспериментальная терапия. - 2003. - № 2. C. 19-23.

20. Стальная Н.Д., Гаришвили Т.Г. Метод определения малонового диальдегида с помощью тиобарбитуровой кислоты. Современные методы в биохимии / под ред. В.Н. Ореховича. - М., 1977. C. 66-68.

21. Тогайбаев А.А, Кургузкин А.В., Рикун И.В. Способ диагностики эндогенной интоксикации // Лабораторное дело. - 1988. - № 9. - С. 22-24.

22. Терехова С.В., Быстрова Н.А., Литвинова Е.С., Гаврилюк $E$. B. Коррекция аллогенными гепатоцитами иммунометаболических нарушений при экспериментальной ишемии печени / Системный анализ и управление в биомедицинских системах. - 2012. - Т. 11, № 2. С. 414-417.

23. Шатохин М.Н., Конопля А.И., Теодорович О.В., Гаврилюк В.П. Иммунометаболический статус и эритроциты при патологии предстательной железы; коррекция нарушений. - М. : Изд-во ГОУ ВПО КГМУ Минздравсоцразвития России, 2012. $152 \mathrm{c}$.

24. Шендер Э.М., Колосов А.Е. Закономерности регенерации гепатоцитов после трансплантации фетальных тканей печени при циррозе печени у крыс. - Вестник новых медицинских технологий. 2009. - T. XVI, № 3. - C. 25-26.

25. Berry M.N., Friend D.S. High-Yield preparation of isolated rat liver parenchymal cells / The Journal of Cell Biology. - 1969. - Vol. 43, N 3. - P. 506-520.

26. Grim E.A., Crump W.L., Durret A., Hester G., LageoDeenadalayon P., Orven-Schaub L.B. TGF-beta inhibits the in vitro induction of lymphokine-activated killing activity // J.Cancer Immunol. Immunother. 1988. - Vol. 27. - P. 53-58.

27. Liu K.X., Kato Y., Matsumoto K., Nakamura T., Kaku-T., Sugiyama $Y$. Characterization of the 
enhancing effect of protamine on the proliferative activity of hepatocyte growth factor in rat hepatocytes // Pharm Res. - 2009. - Vol. 26, N 4. P. 1012-1021.

28. Pollard J.W., Walker J.M. Basic Cell Culture Protocols (Methods in Molecular Biology (Cloth) Totowa, NJ : Humana Press Inc., 1997. - 482 p.
29. Shimizu M., Takakuwa Y., Nitta S. Study of stimulation-secretion coupling in a flow culture system: periodic secretion of hepatocyte growth factor by interleukin-1 alpha-stimulated human embryonic lung fibroblasts // Biochim Biophys Acta. - 1995. Vol. 1244, N 2-3. - P. 357-362. 